\title{
Reproductive ecology of the distylous species Houstonia longifolia: Implications for conservation of a rare species
}

\begin{tabular}{|r|l|}
\hline Journal: & Botany \\
\hline Manuscript ID & cjb-2016-0024.R2 \\
\hline Manuscript Type: & Article \\
\hline Date Submitted by the Author: & 17-May-2016 \\
\hline Complete List of Authors: & $\begin{array}{l}\text { Pedersen, Jennine; University of Alberta, Renewable Resources } \\
\text { Macdonald, S.; University of Alberta, Renewable Resources } \\
\text { Nielsen, Scott; University of Alberta, Renewable Resources }\end{array}$ \\
\hline Keyword: & distylous, self-incompatibility, morph ratio, seed production, Allee effect \\
\hline
\end{tabular}

SCHOLARONE ${ }^{\text {IM }}$

Manuscripts 


\section{Reproductive ecology of the distylous species Houstonia longifolia: \\ Implications for conservation of a rare species}

Jennine L.M. Pedersen, S. Ellen Macdonald, and Scott E. Nielsen

J. L. M. Pedersen, S. E. Macdonald (emacdona@ualberta.ca), and S. E. Nielsen (scottn@ualberta.ca). University of Alberta, Renewable Resources, 751 General Services, Edmonton, AB, Canada T6G 2H1

Corresponding author: Jennine Pedersen (email: jennine1@ualberta.ca, phone: 780 619-2313) 


\begin{abstract}
Distylous species typically experience self-incompatibility with one morph often having partial self-compatibility. Small populations may therefore experience greater rates of selfing/intramorph crosses leading to skewed morph ratios and reduced seed production. For the distylous species Houstonia longifolia ('imperiled' at its northwestern range limit in Alberta) we examined if small populations were morph biased and whether seed production was affected by: population size, local density, plant size, morph type and surrounding morph ratio. For focal plants in several populations we measured size (height, number of stems) and local density (1 $\mathrm{m}^{2}$ ) of pins and thrums with the focal plants collected for seed counts. Population size was estimated from densities in systematically located quadrats in each population. Morph ratios were pin biased in small populations but even to slightly thrum biased in large populations. Critical population size for maintaining an equal morph ratio was $\sim 726$ plants. Seed production was most influenced by the interaction between morph type and surrounding morph ratio which were themselves influenced by population size (Allee effect). Seed production increased for thrums but decreased for pins as the proportion of surrounding pins increased, suggesting strong incompatibility. These results provide guidance on population size and morph ratios for conservation actions.
\end{abstract}

Key words: distylous, self-incompatibility, morph ratio, seed production, Allee effect 


\section{Introduction}

Heterostyly is a type of sexual polymorphism found in 28 plant families where plants produce either two (distyly), or three floral morphs (tristyly) (Barrett 2002). Distylous species exhibit herkogamy within flowers, with pins having long styles and short stamens and thrums having short styles and long stamens (Ganders 1979; Barrett 2002). Thus in pin plants the stigma is positioned above the anthers while the reverse is true in thrum plants. Most distylous plants express heteromorphic incompatibility where only crosses between pins and thrums lead to fertilization (Ganders 1979; Barrett 2002). This incompatibility system is believed to be maintained by the spatial separation of sexual structures in flowers (Barrett 2002), promoting pollen transfer from short stamens to short pistils and long stamens to long pistils (Ganders 1979; Meeus et al. 2012).

In most distylous species pins are recessive homozygous (ss) and thrums are dominant heterozygous (Ss) (Lewis and Jones 1992). This incompatibility system is assumed to result in equal proportions of pin and thrum offspring (i.e. seed), thus maintaining equal morph ratios (Van Rossum et al. 2006; Meeus et al. 2012). However, some distylous species may experience a breakdown of self-incompatibility (Ganders 1979, Barrett 1989, 2013). This breakdown has been shown to occur more frequently for pin morphs (Ganders 1979), although this can vary even within the same family (e.g. Rubacieae family; Bahadur 1970a, Wyatt and Hellwig 1979). These breakdowns are believed to increase selfing and intramorph crosses in those populations experiencing intermorph disruptions leading to morph biases towards the more self-compatible morph (Ganders 1979; Van Rossum et al. 2006; Meeus et al. 2012). Small populations are more likely to experience these disruptions as they are prone to "demographic stochasticity and genetic drift" (Van Rossum et al. 2006), resulting in a lack of compatible mates (Endels et al. 2002; Kery 
et al. 2003; Brys et al. 2008). Large populations are therefore expected to have balanced morph ratios and higher pollination levels, as compared to small populations; this in turn will result in higher levels of intermorph crosses (Kery et al. 2000; Matsumura and Washitani, 2000; Jaquemyn et al. 2002; Kery et al. 2003). This will, further, lead to higher seed production as intermorph crosses result in higher seed sets than intramorph crosses (Beliveau and Wyatt 1999; Shibayama and Kadono 2003; Van Rossum et al. 2006). Thus it is believed that distylous species experience a component Allee effect where seed production is influenced by the morph ratio in varying population sizes through a mechanism of morph biased reproductive incompatibility; similar to the mechanism of "sex ratio fluctuations" as described by Stephens et al. (1999).

Seed production has been shown to differ among floral morphs ( $₫$ gren and Ericson 1996; Beliveau and Wyatt 1999; Matsumura and Washitani 2000; Minuto et al. 2014) and vary with plant size. Larger plants produce more flowers and experience higher pollinator visitation rates (Schmitt 1983; Brothers and Atwell 2014). Likewise, local floral density affects seed production (Feinsinger et al. 1991) with smaller distances between morph types increasing the rate of intermorph crosses (Nicholls 1987; Shibayama and Kadono 2003). Past studies have demonstrated seed set to be positively related to the frequency of pins in a population (Van Rossum et al. 2006; Brys et al. 2008). This is likely due to thrums requiring pins for intermorph crosses, or perhaps pins being more self-compatible allowing for seed production even in the absence of thrums (Ganders 1979). However, no studies to our knowledge have investigated how the number of pins in close proximity to a focal plant of varying morph type affects seed production.

For this study, the reproductive success of the distylous species long-leaved bluet (Houstonia longifolia Gaertner) was investigated. Factors examined included: population size, 
local density, proportion of pins around focal plants, morph type (pin or thrum), and plant size (maximum height and number of stems). Our objectives were to: 1) determine if small populations had morph ratios biased towards the pin morph; this was predicted to be the more self-compatible morph since breakdowns in self-incompatibility occur more frequently for this morph type (Ganders 1979); and 2) examine which factors most influence this species' seed production; for this we tested three hypotheses: component Allee effect, local density and incompatibility. For the component Allee effect hypothesis we predicted that seed production would be positively related to population size and/or even morph ratios. For the local density hypothesis we predicted that increasing local density of $H$. longifolia would increase seed production of a focal plant regardless of the morph ratio. For the incompatibility hypothesis we predicted that seed production of a focal plant would increase with increases in the proportion of the opposite morph in surrounding plants as this would indicate this species has an incompatibility system common for distylous species. Plant size was incorporated in all hypotheses tested as taller multi-stemmed plants are likely to produce more seed.

\section{Materials and methods}

\section{Study species}

The long-leaved bluet (H. longifolia Gaertner; Moss 1983) in the subgenus Chamisme of Terrell $(1991 ; 2007)$ is a distylous perennial forb within the Madder family (Rubiaceae). This species has opposite leaves and purplish to white corollas; each plant consists of multiple (1 to 100) short $(\sim 15 \mathrm{~cm})$ reproductive stems containing multiple flowers in a cyme arrangement (Beliveau and Wyatt 1999; Royer and Dickinson 2007). H. longifolia is found in five Canadian 
provinces (Alberta, Saskatchewan, Manitoba, Ontario, and Quebec) and across the Midwest and eastern USA having a global ranking of G4G5 (NatureServe 2013). The northwestern range limit of the species is in central Alberta where its conservation status is "imperiled" (S2) (NatureServe 2013) and its distribution is restricted to the Central Parkland Natural Subregion (Alberta Conservation Information Management System [ACIMS] 2015). This species is found on sandy woodlands and dunes (Royer and Dickenson 2007), and also along sandy roadside ditches (Pedersen personal observation). It flowers from early June through July (Beliveau and Wyatt 1999) with its seeds in Alberta maturing by September (Pedersen personal observation). Based on one day of observation (June 16, 2015) floral visitors of this species include: Eastern flower thrips (Thysanoptera: Thripidae: Frankliniella tritici (Fitch)), flea beetles (Coleoptera: Chrysomelidae: Altica sp.), hover flies (Diptera: Syrphidae: Paragus haemorrhous Miegen, Sphaerophoria philanthus (Miegen)), bee flies (Diptera: Bombyliidae: Hemipenthes 2 spp.), digger wasps (Hymenoptera: Sphecidae: Ammophila sp.), bees (Hymenoptera: Apidae: Nomada sp., Megachilidae: Osmia 2 spp., Hoplitis pilosifrons (Cresson), Dianthidium sp., Halictidae: Lasioglossum 3 spp.), and ants (Hymenoptera: Formicidae: Formica podzolica Francoeur). This species has ballistic dispersal yet is considered to be dispersal limited as it lacks any seed features designed to improve dispersal (Kershaw et al. 2001), and has small seeds (estimated in our populations to be 11714 seeds per gram; $\mathrm{SE}=969 ; \mathrm{n}=5$ plants, each at 500 seeds).

\section{Study area}

The study was conducted within the Central Parkland Natural Subregion in Alberta which has a mean annual temperature of $2.3^{\circ} \mathrm{C}$, a mean annual precipitation of $441 \mathrm{~mm}$, and 1412 growing degree days above $5^{\circ} \mathrm{C}$ (Natural Regions Committee [NRC] 2006). A mixture of 
deciduous forests and grasslands characterize this area. This region is also considered to have some of the highest levels of habitat fragmentation and habitat loss in Alberta due to oil and gas exploration and exploitation, grazing and agriculture (NRC 2006). Houstonia longifolia populations found within this area were separated by areas of unsuitable habitat, such as forests, wetlands, roadways, and especially cultivated agricultural land.

\section{Focal plant surveys}

Prior to commencement of field work, preliminary investigations were completed including: review of $H$. longifolia phenological characteristics, review of Alberta Conservation Information Management System (ACIMS) occurrence records, consultations with Alberta Native Plant Council (ANPC) members, and searches of suitable sandy habitat using aerial imagery from Google Earth. On this basis a list of sites was generated for survey visits. Meander searches were then used at each site to identify locations with H. longifolia and to determine the extent of detected populations (following rare plant survey methods described in Lancaster 2000; Henderson 2009). Targeted surveys were then undertaken at these sites from late June to midJuly 2014 during the $H$. longifolia flowering period. From these surveys a total of $14 H$. longifolia populations were found within the Central Parkland Natural Subregion (Table 1). Following these targeted surveys, meander surveys were conducted at each location to locate focal plants. Depending on population size, between 4 and 26 individuals ('focal plants') were marked at each of the 14 populations for a total of $210 \mathrm{H}$. longifolia plants (Table 1). Focal plants were chosen based on different densities of $H$. longifolia plants surrounding them with multiple plants of each morph type being included. 
Plants were marked at each location with a flag with an identification number given to indicate site location and morph type. A nail was also placed at the base of each plant and marked with its floral morph as a secondary marker. Although identification of pin and thrum floral morphs could be determined by the naked eye when examined closely, magnifying lenses were also used. For each marked plant, global positioning system (GPS) coordinates were recorded along with the maximum and mean (based on 10 stems) stem height.

\section{Local density and population size}

A $1 \mathrm{~m}^{2}$ circular quadrat was placed around each focal plant and used to quantify local density and the number and proportion of pins and thrums surrounding each focal plant. Some plants surrounding the focal plant lost their flowers before morph identification could occur. These individuals were recorded as unknown, but were still used in calculating local density for each focal plant.

To determine population size we conducted transect searches $(100 \mathrm{~m}$ parallel transects bisecting populations) in July 2014 in each of the 14 populations following survey methods from Henderson (2009). Search intensity at each location varied with the size of the population and visibility of $H$. longifolia (as recommended by Lancaster 2000 and Henderson 2009 for rare plant surveys). For each transect, a $1 \mathrm{~m}^{2}$ circular quadrat was systematically spaced every two to five meters, depending on the terrain and extent of population. In each quadrat the number of individuals present was recorded. Since plants were clumped spatially, individual counts were based on number of rosettes of basal leaves. Distances between transects varied from 3 to 20 meters, again based on terrain and extent of population (Table 1). Only one survey occurred for each population. 
Following each survey, extents of populations were defined using the track function on a GPS (Garmin Oregon 550) and walking the boundary of populations or in some cases using the start and end points of transects to define extents of populations. From these extents, total area $\left(\mathrm{m}^{2}\right)$ of each population was calculated using ArcGIS 10.2.

Total number of individuals in all $1 \mathrm{~m}^{2}$ circular quadrats was divided by the total number of quadrats to estimate average $H$. longifolia density for each population. This average density (per $1 \mathrm{~m}^{2}$ ) was multiplied by the areal extent (total area $\mathrm{m}^{2}$ ) of each population to estimate total H. longifolia population size (Table 1). The standard error for mean density per transect was used to estimate the $95 \%$ confidence interval for population size $(\mathrm{SE} \times 1.96)$.

\section{Seed production}

In September 2014 all 14 populations were re-visited and the 210 focal plants were collected just prior to seed dispersal and full senescence of plants. The capsules of these plants were brittle at the time of collection. Therefore, to prevent the loss of seeds full stems were collected. During collection coin envelopes were placed over each plant, the stems were cut at the base near the basal leaves, and the loose stems were then tipped upside down into the labeled coin envelope. Due to the small size of seeds $(<1 \mathrm{~mm})$, envelopes had their flaps taped and were placed into plastic bags to prevent seed loss during transport. Plastic bags were removed in the lab, and any seeds contained in these bags were transferred to a new coin envelope labeled with

the same ID. Coin envelopes were then placed into brown paper bags and left in a cool dry place to promote further drying and seed ripening.

Due to their small size, seeds for each marked plant were manually counted. For each plant, the number of stems was counted (average number of stems $=17$ ) and any unopened 
capsules containing seeds were opened with tweezers. Magnifying lamps were used to assist with seed counting. To ensure accuracy of seed counts, a sample of plants $(6 \%)$ were double counted with an average error rate estimated at $4.0 \%{ }^{1}$.

\section{Data analyses}

The statistical software package R 3.1.2 was used to conduct all analyses (R Core Team 2014). The largest population ( 49 200 individuals over $40000 \mathrm{~m}^{2}$ ) sampled was removed from analyses since its population size was an order of magnitude larger than any other population (next largest was $~ 5500$ ); with no observations of intermediate population sizes this resulted in a single large outlier in the dataset ${ }^{2}$. Thus we used 190 of the 210 collected focal plants from a total of 13 populations that ranged from $\sim 22$ to $\sim 5500$ individuals of H. longifolia.

Morph ratio was calculated as: (\# Pins - \# Thrum) / (\# Pins + \# Thrums) (Meeus et al. 2012). A morph ratio of -1.0 indicates populations of only thrums and +1.0 indicates populations of only pins, with 0 indicating an equal morph ratio (Meeus et al. 2012). A linear-log regression model using the 'stats' package (R Core Team 2014) was used to determine the effect of population size (log10 transformed) on morph ratio and estimate the population size at which the morph ratio was equal (zero).

We compared eight candidate models (negative binomial generalized linear mixedeffects) to test our hypotheses regarding the factors affecting seed production in $H$. longifolia (Table 2). Data from the 190 focal plants were used for model construction. Model 1 was an ecological base model in which seed production (\# of seeds per plant) was the response variable, location (i.e., population) was a random factor, and measures of plant size (\# stems and

\footnotetext{
${ }^{1}$ See supplemental material for re-count data of Houstonia longifolia seeds.

${ }^{2}$ See supplemental material for analysis which includes largest population.
} 
maximum height) were included as covariates, as size is likely related to seed production. The three models to test the Allee, density and incompatibility hypotheses were constructed by inclusion of population size, local density, or the interaction between morph type and morph ratio (as indicated by proportion pin), respectively, into the ecological base model (Table 2). The interaction between morph type and proportion pin was included for the incompatibility hypothesis model to determine if seed production would vary with morph type of the focal plant and the proportion of morph type (i.e. pins) surrounding it. Four combined models were then produced by incorporating the predictor variables from the Allee, density, and incompatibility hypothesis models in various combinations as follows: an Allee and density hypothesis including population size and local density; an Allee and incompatibility hypothesis including population size, morph type and proportion pin; a density and incompatibility hypothesis including local density, morph type and proportion pin; and an Allee, density and incompatibility hypothesis which incorporated all predictor variables (Table 2). For these eight models all continuous fixed predictor variables including covariates were log transformed to improve model convergence, except for the variable proportion pin that was Arcsine transformed.

Akaike's Information Criteria (AIC) was used to identify the most parsimonious model (Akaike 1974) among the eight candidate models. We used a Chi-square test to determine if the most supported model differed significantly from the ecological base model. For the most supported model we also calculated the correlation between observed and predicted values of seed production to assess model fit. Finally, to examine the nature of the influence of predictor variables on seed production, predicted values of the response variable were graphed for the most supported model. Observed values were used for the factors graphed, while all other factors were held constant at their means. 


\section{Results}

Morph ratios ranged from -0.21 (more thrum than pin) to 0.48 (more pin than thrum) for the 13 populations (Table 1$)$ with morph ratio being negatively related to population size $(\beta=$ $\left.0.22, \mathrm{SE}=0.06 ; \mathrm{p}=0.003, \mathrm{R}^{2}=0.56\right)$. Small populations were pin biased, while large populations were more even to slightly thrum biased (Fig. 1). A population size of 726 individuals (95\% C.I. $=236-3316)$ was predicted to result in an even morph ratio (Fig. 1).

The most supported model for seed production of $H$. longifolia was the incompatibility model including the interaction between morph type and proportion pin, plant size (\# stems and maximum height) as a covariate, and location as a random effect (Table 3 ). This incompatibility model had significantly better fit than the ecological base model $\left(\chi^{2}=30.93, \mathrm{p}<0.001\right)$ with change in AIC $(\triangle \mathrm{AIC}=25)$ being large. In the incompatibility model, plant height, number of stems, and the interaction between morph type and proportion pin were positively related to seed production, with thrum morph and proportion pin negatively related to seed production (Table 4). Seed production in thrums increased with increasing proportion of surrounding pins, while seed production in pins decreased as the proportion of surrounding pins increased (Fig. 2). Pins had greater seed production than thrums across most pin proportions, with pins and thrums producing an equal number of seeds when the proportion of pin plants was $\sim 0.85$ (Fig. 2 ). Thrums were able to produce seed in the absence of pins, but at lower levels than produced by pins in the absence of thrums (Fig. 2). The correlation between observed and predicted values of seed production for the most supported model (Incompatibility Model) was moderate $(\mathrm{r}=0.57)$, suggesting reasonable predictive power for the model, but indicating the existence of other unmeasured or random factors affecting seed production. 


\section{Discussion}

We investigated the reproductive ecology of $H$. longifolia to test hypotheses about the factors influencing seed production and to provide information to guide conservation strategies for this locally "imperiled" species. This study demonstrated that small populations of $H$. longifolia were likely to have flower morph ratios biased towards the pin morph and that seed production was influenced by the interaction between morph type and the surrounding proportion of pins. These results suggest pins are potentially more self-compatible than thrums, but that there is still a strong self-incompatibility system requiring intermorph crosses for high production of seeds.

The relationship between morph ratio and population size followed our predictions with reductions in population size leading to morph biases (Molano-Flores 2001; Endels et al. 2002; Kery et al. 2003), with small populations of $H$. longifolia being pin biased and large populations being more even to thrum biased. These results also show that a loss of individuals from a small population is more likely to result in a morph bias than the loss of individuals from a large population. If a morph bias does occur, fewer intermorph crosses will take place and seed production will decline. Thus, intervention measures such as translocation of the less abundant morph type or hand pollination between pins and thrums may be required (Ågren and Ericson 1996; Molano-flores 2001). Therefore, maintaining an adequate population size is critical to ensure the persistence of this species. We estimate a minimum population size of 726 individuals $(95 \%$ C.I. $=236-3316)$ would be needed to ensure even morph ratios; this can serve as a benchmark for managers to use in future conservation plans. 
Both morph types were able to produce seed in the absence of the opposite morph suggesting this species does not have very strict self-incompatibility. However, the evidence that small populations were pin biased, and that pins had higher seed production than thrums in the absence of the opposite morph, supports the suggestion that pins are more self-compatible than thrums. This greater self-compatibility in pins agrees with what has been found in other species (e.g. Hedyotis nigricans, Pentas lanceloata, Jepsonia heterandra, Primula sieboldii, and Pulmonaria officinalis) (Bahadur 1970a; Bahadur 1970b; Ornduff, 1971; Matsumura and Washitani 2000; Brys et al. 2008). However, future research is still needed to confirm the existence of this greater self-compatibility in the pin floral morph and to determine its strength and underlying mechanisms.

Our analysis revealed results similar to other studies in that larger populations had more even morph ratios (Kery et al. 2000; Matsumura and Washitani 2000; Jacquemyn et al. 2002; Kery et al. 2003). These even morph ratios are likely to result in greater rates of intermorph crosses, in turn leading to higher seed production. This suggests the existence of a component Allee effect for this species through a mechanism of morph bias reproductive incompatibility. That is, the chance of finding a compatible mate (i.e. pin or thrum) increases as population size increases (Courchamp et al. 2008, Gascoigne et al. 2009) leading to greater seed production.

Surprisingly, our density hypothesis (local density) for seed production was less supported than the incompatibility hypothesis, even though numerous studies have shown that the proportion of intermorph crosses is positively related to plant density (Schaal 1978; Nicholls 1987; Shibayama and Kadono 2003). There are several possible explanations for this result. Firstly, this species may experience a phenomenon known as "ideal free distribution" (Fretwell and Lucas 1969) where pollination rates for each flower are equal regardless of the number of 
open flowers (i.e. local density of individuals with open flowers) (Dreisig 1995). Secondly, pollinators may have overlooked even dense patches of this small statured plant to visit nearby more attractive plant species with larger floral displays (Yang et al. 2011; Seifan et al. 2014). Thirdly, the spatial pattern of individuals surrounding a focal plant may have influenced seed production more than the actual local density of individuals (Geslin et al. 2014; Seifan et al. 2014). Fourthly, the scale at which we measured local density $\left(1 \mathrm{~m}^{2}\right)$ may not have been the scale at which density affects seed production. Therefore, pollination levels, spatial pattern and conspecific species surrounding $H$. longifolia should be investigated in future studies.

With distylous species experiencing heteromorphic incompatibility, seed production was predicted to vary by morph type and the proportion of surrounding morph types (Shibayama and Kadono 2003; Van Rossum et al. 2006; Brys et al. 2008). For the distylous species Pulmonaria officinalis, the short-styled morphs relative fecundity (i.e. ratio of mean seed set of short-styled morph over mean seed set of long-styled morph) was positively related to populations with greater long-style morph frequencies (Brys et al. 2008). Similar findings were obtained by Van Rossum et al. (2006) with seed set for Primula veris being positively related to proportion pins and varying among morph types. The most supported model (Incompatibility Model) confirmed these results for $H$. longifolia with the proportion of pins positively related to seed production in thrums, and negatively related to seed production in pins. This result is the same even when the large population ( 49 200 individuals) was included in this analysis ${ }^{3}$. This provides support for the existence of self-incompatibility in this species and illustrates how the occurrence of compatible mates (i.e. even morph ratios), which would increase the chances of intermorph crosses, results in higher seed production. This also indicates that if pin intramorph crosses occur more often as pin proportions increase, seed production for this species would most likely

\footnotetext{
${ }^{3}$ See supplemental material for analysis which includes largest population.
} 
decline. Therefore, any translocation of this species for conservation purposes should consist of equal proportions of pins and thrums to increase the chance of intermorph crosses.

As expected, plant size was positively related to seed production and this can be attributed to the fact that taller, multi-stemmed plants are more likely to have multiple flowers. Data on number of flowers per plant were not collected due to the short flowering period causing a continual loss of flowers during the duration of these surveys. This increase in seed production for taller, multi-stemmed plants could be related to pollination levels. For instance, Schmitt (1983) found stalk height and number of flower heads affected pollinator selection. This pollination selection was also found for $\mathrm{F}_{2}$ hybrids of dioecious Silene species, where visit rates were greater for tall plants with multiple flowers than short plants with few flowers (Brothers and Atwell 2014).

Based on H. longifolia's limited dispersal, current level of habitat fragmentation within its range, and the expected rate of climate change, it has been ranked $10^{\text {th }}$ most vulnerable to climate change out of 419 rare plant species assessed for Alberta (Barber et al. 2015). In order to prevent this species' decline, conservation strategies should formulate strategies that consider this species' incompatibility system and thus focus on the maintenance and establishment of large populations that contain even morph ratios. 


\section{Acknowledgements}

We thank Graeme Nordell, John Acorn and the Alberta Native Plant council for their assistance, as well as Jaime Pinzon for his statistical guidance. Also, we thank Barton Pedersen for his floral morph illustrations. This work was made possible with funding support from the Climate Change and Emissions Management Corporation (CCEMC) Biodiversity Adaptation Grant, the Alberta Biodiversity Monitoring Institute (ABMI), the Canadian Foundation for Innovation (CFI), and the Alberta Conservation Association Challenge Grants in Biodiversity. 


\section{References}

Ågren, J., and Ericson, L. 1996. Population structure and morph-specific fitness differences in tristylous Lythrum salicaria. Evolution 50(1): 126-139. doi:10.2307/2410787.

Akaike, H. 1974. A new look at the statistical model identification. IEEE Trans. Autom. Control 19(6): 716-723. doi:10.1109/TAC.1974.1100705.

Alberta Conservation Information Management System (ACIMS). 2015. ACIMS data [online]. Available from http://www.albertaparks.ca/acims-data\# [accessed 1 May 2014].

Bahadur, B. 1970a. Heterostyly in Hedyotis nigricans (Lam.) Fosb. J. Genet. 60(2): 175-177. doi:10.1007/BF02984156.

Bahadur, B. 1970b. Heterostyly and homostyly in Pentas lanceolata (Forsk.) Delf. J. Genet. 60(2): 199-204. doi:0.1007/BF02984160.

Barber, Q.E., Nielsen, S.E., and Hamann, A. 2015. Assessing the vulnerability of rare plants using climate change velocity, habitat connectivity and dispersal ability: a case study in Alberta, Canada. Reg. Environ. Change, 1-9. doi: 10.1007/s10113-015-0870-6.

Barrett, S.C.H. 1989. The evolutionary breakdown of heterostyly. In The evolutionary ecology of plants. Edited by J.H. Bock, and Y.B. Linhart. Westview Press, Boulder, Co. pp. 151-169

Barrett, S.C.H. 2002. Evolution of sex: the evolution of plant sexual diversity. Nat. Rev. Genet. 3(4): 274-284. doi:10.1038/nrg776.

Barrett, S.C.H. 2013. The evolution of plant reproductive systems: how often are transitions irreversible? Proceedings of the Royal Society B: Biological Sciences 280(1765): 1. doi: 10.1098/rspb.2013.0913.

Beliveau, B.D., and Wyatt, R. 1999. Compatibility relationships in distylous bluets: Houstonia serpyllifolia and H. longifolia (Rubiaceae). Am. Midl. Nat. 141(2): 217-226. 
doi:http://dx.doi.org/10.1674/0003-0031(1999)141[0217:CRIDBH]2.0.CO;2.

Brothers, A.N., and Atwell, J.W. 2014. The role of pollinator-mediated selection in the divergence of floral traits between two closely related plant species. Int. J. Plant Sci. 175(3): 287-295. doi:10.1086/67388.

Brys, R., Jacquemyn, H., and Beeckman, T. 2008. Morph-ratio variation, population size and female reproductive success in distylous Pulmonaria officinalis (Boraginaceae). J. Evol. Biol. 21(5): 1281-1289. doi:10.1111/j.1420-9101.2008.01569.x.

Courchamp, F., Berec, L., and Gascoigne, J. 2008. Allee effects in ecology and conservation. Oxford University Press, Oxford, New York. doi:10.1093/acprof:oso/9780198570301.001.0001.

Dreisig, H. 1995. Ideal free distributions of nectar foraging bumblebees. Oikos 72(2): 161-172. doi: $10.2307 / 3546218$.

Early, R., and Sax, D.F. 2011. Analysis of climate paths reveals potential limitations on species range shifts. Ecol. Lett. 14(11): 1125-1133. doi:10.1111/j.1461-0248.2011.01681.x.

Endels, P., Jacquemyn, H., Brys, R., Hermy, M., and De Blust, G. 2002. Temporal changes (1986-1999) in populations of primrose (Primula vulgaris Huds.) in an agricultural landscape and implications for conservation. Biol. Conserv. 105(1): 11-25. doi:10.1016/S0006-3207(01)00173-2.

Feinsinger, P., Tiebout III, H.M., and Young, B.E. 1991. Do tropical bird-pollinated plants exhibit density-dependent interactions? Field experiments. Ecology 72(6): 1953-1963. doi: $10.2307 / 1941550$.

Fretwell, S.D., and Lucas, H.L. 1969. On territorial behavior and other factors influencing habitat distribution in birds. Acta Biotheor. 19(1): 16-36. doi:10.1007/BF01601953. 
Ganders, F.R. 1979. The biology of heterostyly. N. Z. J. of Botany 17(4): 607-635. doi:10.1080/0028825X.1979.10432574.

Gascoigne, J., Berec, L., Gregory, S., and Courchamp, F. 2009. Dangerously few liaisons: a review of mate-finding Allee effects. Popul. Ecol. 51(3): 355-372. doi:10.1007/s10144009-0146-4.

Geslin, B., Baude, M., Mallard, F., and Dajoz, I. 2014. Effect of local spatial plant distribution and conspecific density on bumble bee foraging behaviour. Ecol. Entomol. 39(3): 334342. doi:10.1111/een.12106.

Henderson, D. 2009. Occupancy survey guidelines for prairie plant species at risk. Canadian Wildlife Service, Prairie and Northern Region, Environment Canada, Saskatoon, Saskatchewan. Available from http://www.npss.sk.ca/docs/2_pdf/Rare_Plant_Occupancy_Survey_Guidelines.pdf [accessed 18 May 2014].

Jacquemyn, H., Brys, R., and Hermy, M. 2002. Patch occupancy, population size and reproductive success of a forest herb (Primula elatior) in a fragmented landscape. Oecologia 130(4): 617-625. doi:10.1007/s00442-001-0833-0.

Kery, M., Matthies, D., and Spillmann, H.-H. 2000. Reduced fecundity and offspring performance in small populations of the declining grassland plants Primula veris and Gentiana lutea. J. Ecol. 88(1): 17-30. doi:10.1046/j.1365-2745.2000.00422.x.

Kery, M., Matthies, D., and Schmid, B. 2003. Demographic stochasticity in population fragments of the declining distylous perennial Primula veris (Primulaceae). Basic Appl. Ecol. 4(3): 197-206. doi:10.1078/1439-1791-00142.

Kershaw, L. J., Gould, J., Johnson, J.D., and Lancaster, J. 2001. Rare vascular plants of Alberta. 
University of Alberta Press, Edmonton.

Lancaster, J. 2000. ANPC Guidelines for rare plant surveys in Alberta. Alberta Native Plant Council. Edmonton. Available from http://anpc.ab.ca/wpcontent/uploads/2015/01/rareplant.pdf [accessed 18 May 2014].

Lewis, D., and Jones, D.A. 1992. The genetics of heterostyly. In Evolution and function of heterostyly. Edited by S.C.H. Barrett. Springer Berlin Heidelberg. pp. 129-150. doi:10.1007/978-3-642-86656-2_5.

Matsumura, C., and Washitani, I. 2000. Effects of population size and pollinator limitation on seed-set of Primula sieboldii populations in a fragmented landscape. Ecol. Res. 15(3): 307-322. doi:0.1046/j.1440-1703.2000.00350.x.

Meeus, S., Honnay, O., Brys, R., and Jacquemyn, H. 2012. Biased morph ratios and skewed mating success contribute to loss of genetic diversity in the distylous Pulmonaria officinalis. Ann. Bot. 109(1): 227-235. doi:10.1093/aob/mcr272.

Minuto, L., Guerrina, M., Roccotiello, E., Roccatagliata, N., Mariotti, M.G., and Casazza, G. 2014. Pollination ecology in the narrow endemic winter-flowering Primula allionii (Primulaceae). J. Plant Res. 127(1): 141-150. doi:10.1007/s10265-013-0588-9.

Molano-Flores, B. 2001. What can happen to heterostylous species in prairie restorations? The case of Lithospermum canescens (Boraginaceae). In Proceedings of the $17^{\text {th }}$ North American Prairie Conference: seeds for the future, roots of the past. North Iowa Area Community College, Mason City, Iowa, 16 June-20 June 2000. Edited by N.P. Bernstein and L.J. Ostrander. pp. 88-91.

Moss, E.H. 1983. Flora of Alberta. Second Edition: Revised by J.G. Packer. University of Toronto Press, Toronto. 
Natural Regions Committee (NRC). 2006. Natural region and subregions of Alberta. Compiled by Downing DJ, Pettapiece WW. Government of Alberta. Pub. No. T/852. Available from http://www.albertaparks.ca/media/2942026/nrsrcomplete_may_06.pdf [accessed 18 May 2014].

NatureServe. 2013. NatureServe Explorer: An online encyclopedia of life [online]. Available from http://www.natureserve.org/explorer [accessed 8 May 2015].

Nicholls, M.S. 1987. Pollen flow, self-pollination, and gender specialization - factors affecting seed set in the tristylous species Lythrum salicaria (Lythraceae). Plant Syst. Evol. 156(3): 151-157. doi:10.1007/BF00936070.

Ornduff, R. 1971. The reproductive system of Jepsonia heterandra. Evolution 25(2): 300-311. doi: $10.2307 / 2406923$.

R Core Team. 2014. R: A language and environment for statistical computing. R Foundation for Statistical Computing, Vienna, Austria. Available from http://www.R-project.org/ [accessed 18 August 2014].

Royer, F., and Dickinson, R. 2007. Plants of Alberta : trees, shrubs, wildflowers, ferns, aquatic plants and grasses. Long Pine Publishing, Edmonton.

Schaal, B. A. 1978. Density dependent foraging on Liatris pycnostachya. Evolution 32(2): $452-$ 454. doi:10.2307/2407611.

Schmitt, J. 1983. Flowering plant density and pollinator visitation in Senecio. Oecologia 60(1): 97-102. doi:10.1007/BF00379326.

Seifan, M., Hoch, E.-M., Hanoteaux, S., and Tielborger, K. 2014. The outcome of shared pollination services is affected by the density and spatial pattern of an attractive neighbour. J. Ecol. 102(4): 953-962. doi:10.1111/1365-2745.12256. 
Shibayama, Y., and Kadono, Y. 2003. Floral morph composition and pollen limitation in the seed set of Nymphoides indica populations. Ecol. Res. 18(6): 725-737. doi:10.1111/j.1440-1703.2003.00591.x.

Ste-Marie, C., Nelson, E.A., Dabros, A., and Bonneau, M.E. 2011. Assisted migration: introduction to a multifaceted concept. For. Chron. 87(6): 724-730. doi:10.5558/tfc2011089.

Stephens, P.A., Sutherland, W.J., and Freckleton, R.P. 1999. What is the Allee effect? Oikos 87(1): 185-190. doi:10.2307/3547011.

Terrell, E.E. 1991. Overview and annotated list of North American species of Hedyotis, Houstonia, Oldenlandia (Rubiaceae), and related genera. Phytologia 71(3): 212-243.

Terrell, E.E. 2007. Relationships of Houstonia prostrate (Rubiaceae) of Mexico and Arizona and a review of Houstonia subgenera and sections. Journal of the Botanical Research Institute of Texas 1(1): 109-119.

Van Rossum, F., De Sousa, S.C., and Triest, L. 2006. Morph-specific differences in reproductive success in the distylous Primula veris in a context of habitat fragmentation. Acta Oecol. 30(3): 426-433. doi:10.1016/j.actao.2006.06.005.

Wyatt, R., and Hellwig, R.L. 1979. Factors determining fruit set in heterostylous bluets, Houstonia caerulea (Rubiaceae). Syst. Bot. 4(2): 103-144. doi:10.2307/2418849.

Yang, S., Ferrari, Matthew J., and Shea, K. 2011. Pollinator behavior mediates negative interactions between two congeneric invasive plant species. Am. Nat. 177(1): 110-118. doi:10.1086/657433. 


\section{Tables}

Table 1. Summary of Houstonia longifolia populations included in the study and details of sampling and plant collection for each.

\begin{tabular}{|c|c|c|c|c|c|c|c|c|c|}
\hline Locations & Latitude & Longitude & $\begin{array}{c}\# \text { of } \\
\text { Transects }\end{array}$ & $\begin{array}{c}\text { Spacing } \\
\text { between } \\
\text { Transects }(\mathrm{m})\end{array}$ & $\begin{array}{l}\text { Average Density } \\
\left(\# \text { plants } / \mathrm{m}^{2}(\mathrm{SE})\right)\end{array}$ & $\begin{array}{l}\text { Total Area } \\
\left(\mathrm{m}^{2}\right)\end{array}$ & $\begin{array}{l}\text { Population } \\
\text { Estimates } \\
(95 \% \mathrm{CI})\end{array}$ & $\begin{array}{l}\text { \# Focal } \\
\text { Plants } \\
\text { Collected }\end{array}$ & $\begin{array}{l}\text { Morph Ratio } \\
(95 \% \mathrm{CI})\end{array}$ \\
\hline Gibbons Field (Private Property) & \multicolumn{2}{|c|}{ confidential } & 20 & 10 & $1.23(0.45)$ & 40000.0 & $\begin{array}{c}49200 \\
(+/-35220)\end{array}$ & 20 & $-0.12(+/-0.31)$ \\
\hline Gibbons Dune & 53.863 & 113.319 & 9 & 15 & $0.55(0.46)$ & 10000.0 & $\begin{array}{c}5500 \\
(+/-8979)\end{array}$ & 23 & $-0.21(+/-0.29)$ \\
\hline $\begin{array}{l}\text { North Bruderheim Provincial Recreation } \\
\text { Area }\end{array}$ & 53.856 & 112.934 & 82 & 20 & $0.02(0.03)$ & 200180.5 & $\begin{array}{c}4004 \\
(+/-3652)\end{array}$ & 26 & $-0.15(+/-0.27)$ \\
\hline West Bruderheim & 53.865 & 112.928 & 18 & $\begin{array}{l}5 \text { (small areas) } \\
\text { or } 10 \text { (large } \\
\text { areas) }\end{array}$ & $0.16(0.11)$ & 19514.1 & $\begin{array}{c}3122 \\
(+/-4313)\end{array}$ & 23 & $-0.13(+/-0.29)$ \\
\hline Northwest of Bruderheim Natural Area & 53.85 & 113.029 & 25 & 4 & $0.12(0.07)$ & 13327.2 & $\begin{array}{c}1599 \\
(+/-1859)\end{array}$ & 23 & $0.19(+/-0.29)$ \\
\hline East Bruderheim & 53.867 & 112.923 & 27 & $\begin{array}{c}5 \text { (small areas) } \\
\text { or } 10 \text { (large } \\
\text { areas) }\end{array}$ & $0.06(0.03)$ & 16809.9 & $\begin{array}{c}1009 \\
(+/-954)\end{array}$ & 13 & $0.01(+/-0.39)$ \\
\hline Pipeline clearing near Andrew, $\mathrm{AB}$ & 53.981 & 112.759 & 20 & 5 & $0.07(0.02)$ & 11800.0 & $\begin{array}{c}826 \\
(+/-513)\end{array}$ & 9 & $-0.04(+/-0.46)$ \\
\hline Lily Lake Natural Area & 53.949 & 113.372 & 7 & 4 & $0.16(0.12)$ & 3746.0 & $\begin{array}{c}599 \\
(+/-905)\end{array}$ & 4 & $-0.02(+/-0.69)$ \\
\hline Fort Saskatchewan Prairie & 53.681 & 113.27 & 20 & 15 & $0.02(0.01)$ & 27193.0 & $\begin{array}{c}544 \\
(+/-777)\end{array}$ & 12 & $0.02(+/-0.40)$ \\
\hline Bellis Lake Natural Area & 54.115 & 112.173 & 52 & $\begin{array}{l}5 \text { (small areas) } \\
\text { or } 10 \text { (large } \\
\text { areas) }\end{array}$ & $0.02(0.00)$ & 26983.0 & $\begin{array}{c}540 \\
(+/-426)\end{array}$ & 25 & $-0.23(+/-0.28)$ \\
\hline Ditches near Smokey lake & 54.046 & 112.357 & 6 & 3 & $0.19(0.12)$ & 1145.6 & $\begin{array}{c}218 \\
(+/-278)\end{array}$ & 14 & $-0.11(+/-0.37)$ \\
\hline Property near Bruderheim & \multicolumn{2}{|c|}{ confidential } & 3 & 3 & $0.45(0.36)$ & 162.8 & $\begin{array}{c}73 \\
(+/-114)\end{array}$ & 6 & $0.45(+/-0.56)$ \\
\hline Berm of Wellsite & 53.833 & 113.052 & 6 & 3 & $0.02(0.01)$ & 1121.0 & $\begin{array}{c}22 \\
(+/-20)\end{array}$ & 7 & $0.20(+/-0.62)$ \\
\hline Railway Park & 53.811 & 113.051 & 5 & 3 & $0.08(0.04)$ & 272.3 & $\begin{array}{c}22 \\
(+/-23)\end{array}$ & 5 & $0.48(+/-0.52)$ \\
\hline
\end{tabular}


Note: West Bruderheim refers to Northwest of Bruderheim Provincial Recreation Area on the west side of the Range Rd 204, whereas East Bruderheim refers to this recreational area on the east side of the road. Spacing between transects was $5 \mathrm{~m}$ for Gibbons field and Gibbons Dune and $2 \mathrm{~m}$ for all other locations. Population size estimates $(95 \% \mathrm{CI})$ were calculated by multiplying average density $\left(\#\right.$ plants $\left./ \mathrm{m}^{2}\right)$ by total habitat area $\left(\mathrm{m}^{2}\right)$. Morph ratio (Pin-Thrum/(Pin+ Thrum)) values range from -1 (all thrums) to $+1($ all pins) with 0 indicating equal proportions of the two morphs. 
Table 2. Hypotheses (candidate models) for predicting seed production in Houstonia longifolia.

\begin{tabular}{|c|c|c|}
\hline Hypothesis & Model & Predictions \\
\hline Ecological Base & $\mathrm{L}+\mathrm{S}+\mathrm{H}$ & $\begin{array}{l}\text { Plant size (maximum height and \# of stems) predicted to be positively } \\
\text { related to seed production. }\end{array}$ \\
\hline Allee (population size) & $\mathrm{L}+\mathrm{S}+\mathrm{H}+\mathrm{N}$ & Population size predicted to be positively related to seed production. \\
\hline Density (local density) & $\mathrm{L}+\mathrm{S}+\mathrm{H}+\mathrm{D}$ & Local density predicted to be positively related to seed production. \\
\hline Allee \& Density & $\mathrm{L}+\mathrm{S}+\mathrm{H}+\mathrm{N}+\mathrm{D}$ & $\begin{array}{l}\text { Population size and local density predicted to be positively related to seed } \\
\text { production. }\end{array}$ \\
\hline Incompatibility & $\mathrm{L}+\mathrm{S}+\mathrm{H}+\mathrm{M} * \mathrm{P}$ & $\begin{array}{l}\text { Incompatibility system predicted to influence seed production; i.e., seed } \\
\text { production of a focal thrum plant predicted to be positively related to } \\
\text { proportion of pin plants in the surrounding area and in focal pin plants to } \\
\text { be negatively related to proportion of pins; this effect could be stronger for } \\
\text { thrum than for pin plants. }\end{array}$ \\
\hline Allee \& Incompatibility & $\mathrm{L}+\mathrm{S}+\mathrm{H}+\mathrm{N}+\mathrm{M}^{*} \mathrm{P}$ & $\begin{array}{l}\text { Incompatibility system (as above) and population size predicted to be } \\
\text { positively related to seed production. }\end{array}$ \\
\hline Density \& Incompatibility & $\mathrm{L}+\mathrm{S}+\mathrm{H}+\mathrm{D}+\mathrm{M} * \mathrm{P}$ & $\begin{array}{l}\text { Incompatibility system (as above) and local density predicted to be } \\
\text { positively related to seed production }\end{array}$ \\
\hline $\begin{array}{l}\text { Allee, Density \& } \\
\text { Incompatibility }\end{array}$ & $\mathrm{L}+\mathrm{S}+\mathrm{H}+\mathrm{N}+\mathrm{D}+\mathrm{M} * \mathrm{P}$ & $\begin{array}{l}\text { Incompatibility system (as above) and both population size and local } \\
\text { density predicted to be positively related to seed production. }\end{array}$ \\
\hline $\mathrm{L}=$ location (random) & $\mathrm{H}=$ maximum plant height & \\
\hline $\mathrm{S}=\#$ of stems & $\mathrm{M}=$ morph & \\
\hline $\mathrm{N}=$ population size & $\mathrm{P}=$ proportion pin & \\
\hline \multicolumn{3}{|c|}{ at surrounding focal plants) } \\
\hline
\end{tabular}


Table 3. Comparison of eight candidate (negative binomial generalized linear mixed-effects) models used to predict seed production in Houstonia longifolia.

\begin{tabular}{llcccc}
\hline \multicolumn{1}{c}{ Hypothesis } & \multicolumn{1}{c}{ Model Structure } & $K$ & AIC & $\Delta$ AIC & $w_{i}$ \\
\hline Incompatibility & $\mathrm{L}+\mathrm{S}+\mathrm{H}+\mathrm{M}^{*} \mathrm{P}$ & 6 & 2814.6 & 0.0 & 0.463 \\
Allee \& Incompatibility & $\mathrm{L}+\mathrm{S}+\mathrm{H}+\mathrm{N}+\mathrm{M}^{* \mathrm{P}}$ & 7 & 2816.0 & 1.4 & 0.230 \\
Density \& Incompatibility & $\mathrm{L}+\mathrm{S}+\mathrm{H}+\mathrm{D}+\mathrm{M}^{* \mathrm{P}}$ & 7 & 2816.2 & 1.6 & 0.208 \\
Allee \& Density \& Incompatibility & $\mathrm{L}+\mathrm{S}+\mathrm{H}+\mathrm{N}+\mathrm{D}+\mathrm{M}^{*} \mathrm{P}$ & 8 & 2817.7 & 3.1 & 0.098 \\
Density (local density) & $\mathrm{L}+\mathrm{S}+\mathrm{H}+\mathrm{D}$ & 5 & 2828.2 & 13.6 & $<0.001$ \\
Allee \& Density & $\mathrm{L}+\mathrm{S}+\mathrm{H}+\mathrm{N}+\mathrm{D}$ & 6 & 2829.5 & 14.9 & $<0.001$ \\
Allee (populations size) & $\mathrm{L}+\mathrm{S}+\mathrm{H}+\mathrm{N}$ & 5 & 2838.1 & 23.5 & $<0.001$ \\
Ecological Base & $\mathrm{L}+\mathrm{S}+\mathrm{H}$ & 4 & 2839.6 & 25.0 & $<0.001$ \\
\hline $\mathrm{L}=$ location (random) & $\mathrm{H}=$ maximum plant height & & & \\
$\mathrm{S}=$ \# of stems & $\mathrm{M}=$ morph & & & & \\
$\mathrm{N}=$ population size & $\mathrm{P}=$ proportion pin & & & & \\
$\mathrm{D}=$ density & & & & & \\
\hline
\end{tabular}

Note: $\triangle$ AIC refers to the difference in AIC from the most supported Incompatibility Model. $\mathrm{w}_{\mathrm{i}}$ refers to the Akiake weight of each model. 
Table 4. Summary of estimates for different parameters in the most supported model (Incompatibility Model in Table 3) of seed production in Houstonia longifolia.

\begin{tabular}{ccc}
\hline Fixed Effect & $\beta$ & SE \\
\hline $\log ($ Stems) & 0.761 & 0.082 \\
$\log$ (Maximum Height) & 1.054 & 0.234 \\
Morph (Thrum) & -1.092 & 0.207 \\
Proportion Pin & -0.862 & 0.165 \\
Morph (Thrum) : Proportion Pin & 1.261 & 0.351 \\
\hline
\end{tabular}

Note: Plant size (stems and maximum height) included as a covariate with location as a random effect. 


\section{Figure Captions}

Fig. 1 Linear-log model of average morph ratio in Houstonia longifolia by population size.

Note: Morph ratio varies between -1.0 (only thrum morphs) to 1.0 (only pin morphs). Isoplethy is indicated by the horizontal line at 0.0 . The mean (linear-log regression) relationship between morph bias and population size is shown by the solid line, with the upper and lower $95 \% \mathrm{CI}$ indicated by the dashed lines.

Fig. 2 The relationship between proportion of surrounding pins and seed production in Houstonia longifolia for plants of each morph type based on the most supported model (see Table 4). Other predictor variables in the model were held constant at their means. 


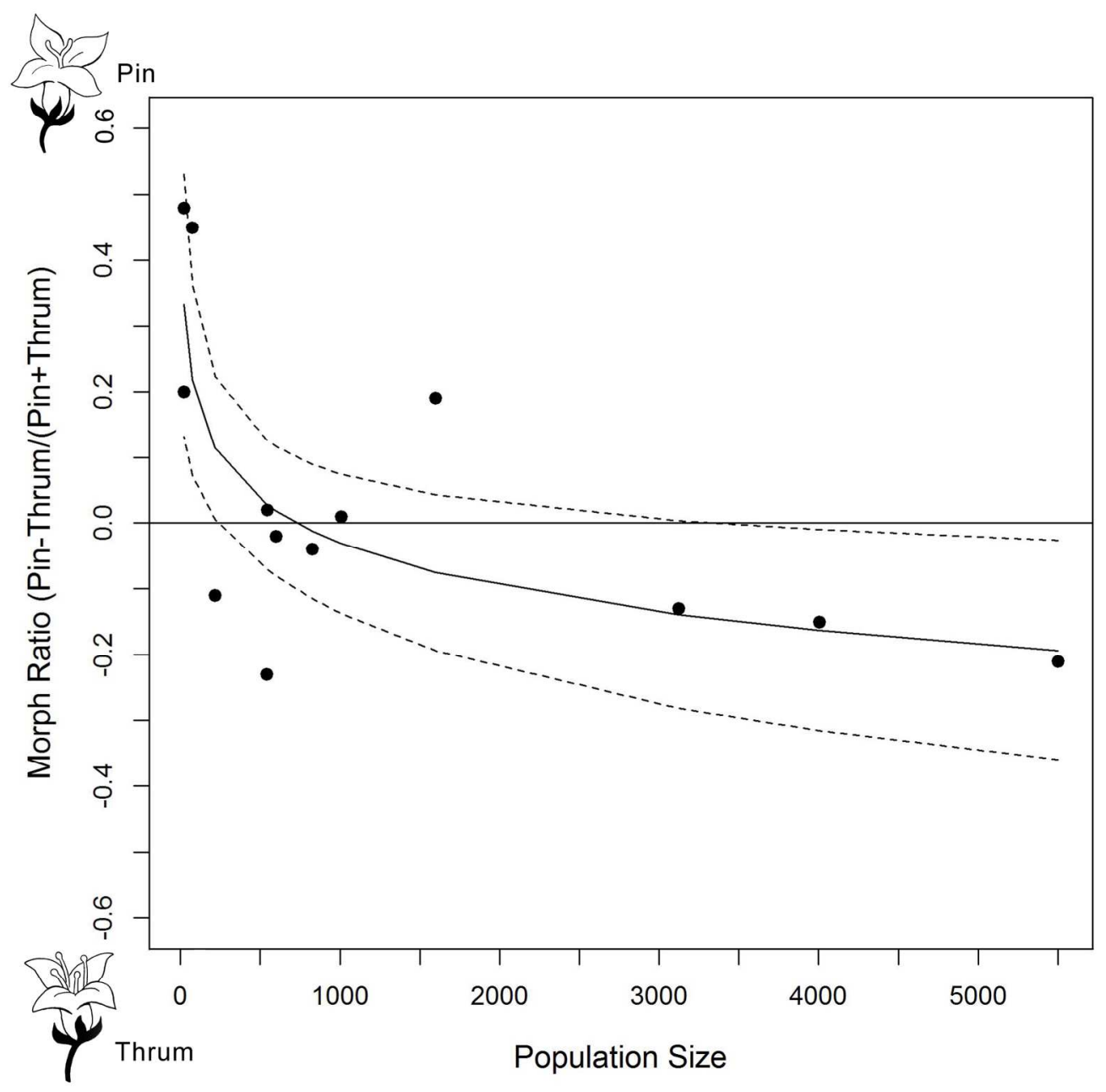

Fig. 1 Linear-log model of average morph ratio in Houstonia longifolia by population size.

Note: Morph ratio varies between -1.0 (only thrum morphs) to 1.0 (only pin morphs). Isoplethy is indicated by the horizontal line at 0.0 . The mean (linear-log regression) relationship between morph bias and population size is shown by the solid line, with the upper and lower $95 \% \mathrm{CI}$ indicated by the dashed lines. $182 \times 178 \mathrm{~mm}(300 \times 300 \mathrm{DPI})$ 


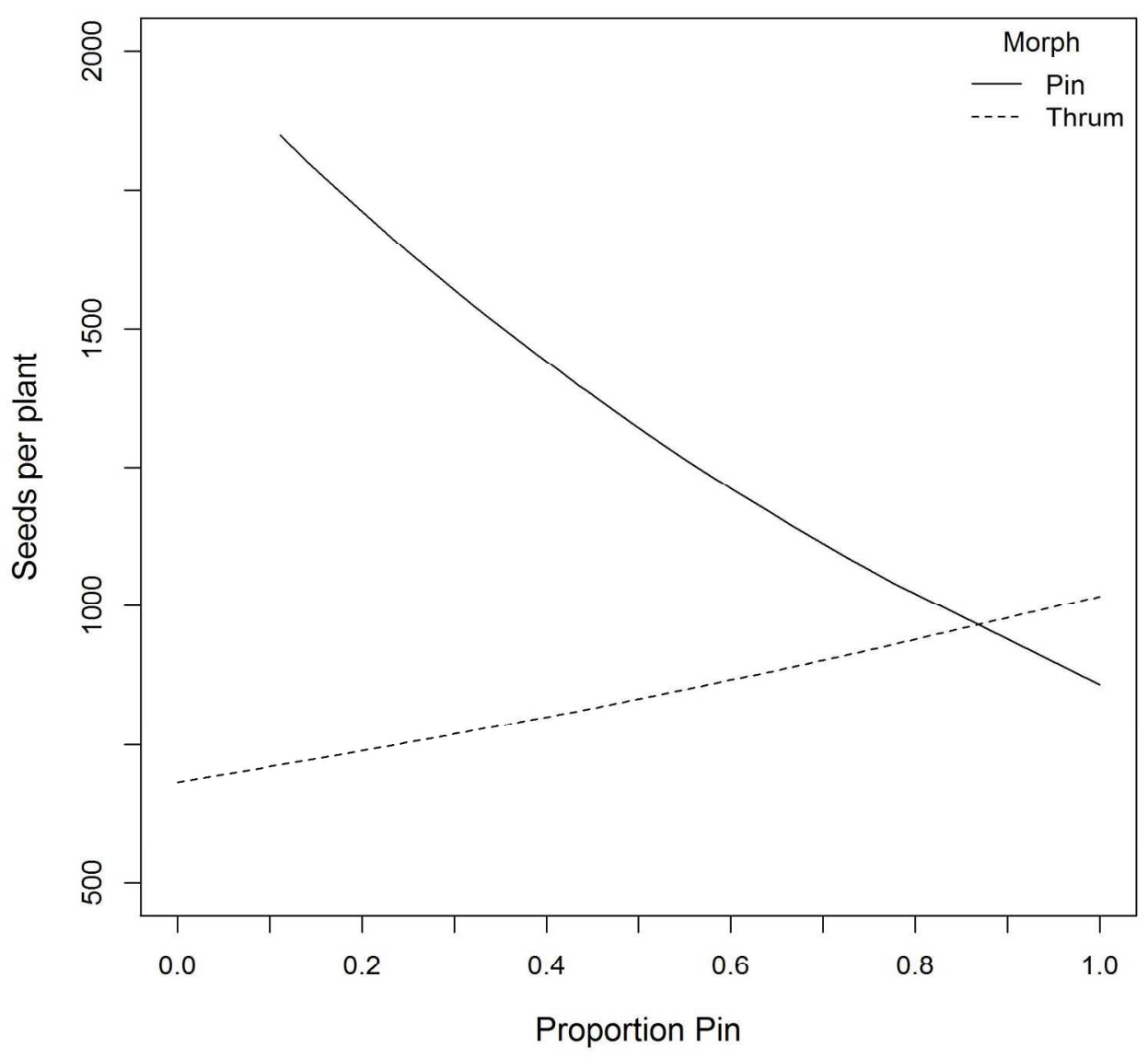

Fig. 2 The relationship between proportion of surrounding pins and seed production in Houstonia longifolia for plants of each morph type based on the most supported model (see Table 4). Other predictor variables in the model were held constant at their means.

$185 \times 185 \mathrm{~mm}(300 \times 300 \mathrm{DPI})$ 